\title{
Split-calving for production and profit
}

\begin{abstract}
Calving cows in both autumn and spring (splitcalving) has increased production and profit. Feed demand has been changed to better suit the pasture growth pattern on the farm. Demand has been increased in winter when pasture can be grown, and reduced in the summer dry period. Cow numbers are still maintained through the spring to utilise pasture efficiently as it grows. Split-calving evens out seasonal variations, giving consistency of production and cashflow. The work-load is also spread, providing better employment conditions and opportunities.
\end{abstract}

K eywords: feed demand, flexibility, profit, splitcalving

\section{The farm}

We have farmed the Maungatapere farm for the last 26 years. Originally the farm was used for effluent disposal from the Maungatapere Dairy Factory. However, when the Kauri complex opened in 1989, production ceased at Maungatapere and the farm was no longer required for effluent disposal. It is now in private ownership.

Area: $\quad 160$ ha total, 151 ha effective

Soils: $\quad 30$ ha clay, 6 ha peaty loam, 115 ha stony volcano

Fertility: All levels adequate to high

Contour: Flat to easy rolling

Subdivision: 66 Paddocks

Cow Nos: $\quad 380-400$ cows. Replacements grazed off.
We were trying to practise all the recommended techniques of concentrated calving and early calving, and aiming for a high peak with well-fed, goodconditioned cows. But dry weather could cut into the production any time from December onwards. Our cows were not performing to their potential. Average production was around $245 \mathrm{~kg}$ milksolids (138 $\mathrm{kg}$ fat).

Many cows had short lactations and it was a constant struggle to rebuild cow condition.

\section{W hy change?}

1. Production was not increasing.

2. Effluent disposal had ceased.

3. The farm grows good grass in winter.

4. We wanted to improve per cow production.

5. Graeme Ferrier, working for the Northland Dairy Co., was wanting to prove the viability of autumn calving.

6. There was a financial incentive (winter premium) to change.

\section{How did we change?}

We went out and bought empty high breeding index young cows in the early summer when they were being "strategically" dried off and culled. These were mated in the early winter to start calving the following March. We started with about a quarter of the herd calving in the autumn, then'went to one third and are currently heading towards a 50:50 split. Depending on the winter premium paid, we could increase the autumn calving even further.

\section{M anagement}

The farm was a traditional late-winter, earlyspring calving herd throughout its effluent disposal days. Although the effluent gave some summer irrigation benefit, it was still very prone to the impact of summer droughts. And besides that, the effluent was a real complication to management $\mathrm{We}$ were glad to be rid of it.

During these years, production varied quite significantly due to dry summers (refer Table 1).
Table I Seasonal calving 1985/86-1989/90.

\begin{tabular}{lrrrrrrr}
\hline Season & $\mathbf{8 9 / 9 0}$ & $\mathbf{8 8 1 8 9}$ & $\mathbf{8 7 1 8 8}$ & $\mathbf{8 6 / 8 7}$ & $\mathbf{8 5} / 86$ & Average & Variability \\
\hline J.J.A. & 11825 & 11317 & 9680 & 10328 & 10730 & $12 \%$ & $\mathbf{\pm} 10 \%$ \\
S.O.N. & $\mathbf{3 5 2 6 0}$ & $\mathbf{3 7 1 4 9}$ & $\mathbf{4 2 9 2 6}$ & $\mathbf{4 2 8 4 1}$ & $\mathbf{3 8 6 0 6}$ & $\mathbf{4 1 \%}$ & $\pm 10 \%$ \\
D.J.F. & 29186 & 30776 & 32463 & 28177 & 33068 & $\mathbf{3 2 \%}$ & $\mathbf{\pm} \%$ \\
M.A.M. & 16150 & 9338 & 21181 & 13673 & 14292 & $15 \%$ & $\pm \mathbf{4 0 \%}$ \\
Total s & & & & & & & \\
Milksolids & 92421 & 88580 & $\mathbf{1 0 6 2 5 0}$ & 94999 & 96696 & 95789 & $\pm 9 \%$ \\
(Fat) & $\mathbf{( 5 2 4 2 3 )}$ & $(\mathbf{5 0 0 4 5 )}$ & $\mathbf{( 6 0 0 5 9 )}$ & $\mathbf{( 5 3 2 3 8 )}$ & $\mathbf{( 5 4 7 2 6 )}$ & $\mathbf{( 5 4 0 9 8 )}$ & \\
\hline Peak cows & $\mathbf{3 8 2}$ & $\mathbf{3 9 9}$ & $\mathbf{3 8 9}$ & $\mathbf{3 8 5}$ & $\mathbf{4 0 1}$ & $\mathbf{3 9 2}$ & \\
Per cow & $\mathbf{2 4 2}$ & $\mathbf{2 2 2}$ & $\mathbf{2 7 3}$ & $\mathbf{2 4 7}$ & $\mathbf{2 3 9}$ & $\mathbf{2 4 4}$ & \\
\hline
\end{tabular}




\section{W hat are the results?}

We have increased production; we have increased profit; we have reduced stock wastage allowing more stock sales; and we have generally made a $\$ 50$ premium for our autumn calves.

Split-calving is a very flexible and resilient system. Our work-load is more evenly spread. In some ways it requires more planning and organising but we have less "peak" pressures and our staff generally enjoy the system.

Our basic philosophy is keep the system as simple as possible. We focus on the stock management and particularly milking, and then attend to other jobs in order of priority. We do not go looking for extra work.

We make no silage owing to the stony soils; we don't crop and we make a small amount of hay. We have little machinery. With split-calving we can vary stock numbers to cope with the pressure times. For example, February is now our lowest pressure point, although March and the start of autumn calving has become possibly more critical. Peak numbers are maintained in spring to utilise the grass as it grows.

We feed budget, and use rotation length to maintain adequate feed cover while trying to achieve adequate feed intakes and pasture utilisation. More nitrogen is now being used, although we are still relatively low users - approximately 45 units $\mathrm{N} / \mathrm{ha}$.

Production has increased by over $20 \%$ from basically the same number of cows (Table 2). But the Northland average has also increased over the same time by $7 \%$ (Herd Test Data). So net gain with this management system has been $13 \%$.

Table 2 Split-calving 1990/91-1994/95.

\begin{tabular}{lrrrrrrr}
\hline Season & $94 / 95$ & $93 / 94$ & $92 / 93$ & $91 / 92$ & $90 / 91$ & Average & Variability \\
\hline J.J.A & 22353 & 15464 & 17249 & 20292 & 13292 & $16 \%$ & $\pm 25 \%$ \\
S. Q N & 49102 & 52361 & 44560 & 45977 & 46387 & $43 \%$ & $\pm 8 \%$ \\
D. J. F. & 22285 & 32283 & 29529 & 28706 & 23644 & $24 \%$ & $\pm 18 \%$ \\
MA M & 18993 & 15422 & 23625 & 15211 & 23388 & $17 \%$ & $\pm 22 \%$ \\
Total s & & & & & & & \\
M I ksol i ds & 112733 & 115550 & 114963 & 110192 & 106711 & 112030 & \pm \\
(Fat) & 64045 & 68012 & 65734 & 63541 & 61251 & 64499 & \\
\hline Peak cows & 399 & 388 & 370 & 381 & 368 & 381 & \\
Per cow & 283 & 298 & 311 & 289 & 290 & 294 & \\
\hline
\end{tabular}

The autumn cows have long "flat" lactation curves, and are dried off when the pressure comes on in December or January. This takes the pressure off the spring calvers, which allows them to also produce better. Even so, the spring cows tend to peak high and then fall away rapidly as feed quality and quantity declines in the summer.

\section{Split-calving}

Autumn calvers av. 335-350 kg MS/cow (195-200 fat). Spring calvers av. 275-290 kg MS/cow (155-160 fat).

\section{Seasonal calving}

Spring calvers av. 220-270 kg MS/cow (145-150 fat).

\section{Why does it work?}

We aim to utilise pasture as it grows. With split-calving we do not build up the large wedge of food like we did with seasonal calving. So we do not have areas of possibly over-long grass suppressing growth rate. Nor do we have a large area of the farm intensively blockgrazed again suppressing growth in the winter.

We still have our aim to have the same average feed cover through the winter. But it is a flatter wedge, because we are feeding milking cows. We have higher residuals. Perhaps we are now maintaining our pastures in better growing conditions through the winter.

Our cycle of cow condition is certainly much better. Late lactation for the autumn calvers is through the spring so they put on condition and are typically dried off in a condition score of $5 \frac{1}{2}$ or 6 . We graze the dry autumn calvers off the farm. It doesn't take much feed to hold condition at that time of the year, and by getting them off, we take pressure off both the spring calvers and the pastures.

As a result, the spring calvers now hold their condition better because we have reduced the stocking rate by $40 \%$. And we are probably doing less summer overgrazing of our pastures.

Under our old seasonal pattern, we used to cull and dry off strategically. But we still tried to get as many milkers through the dry summers as we possibly could. This was done to try to exploit any good autumn flush. But all we seemed to achieve was low-condition cows and overgrazed pastures. Then it became a battle to rebuild both cow condition and feed cover ready for the new season.

Despite the recent run of dry summers and autumns, we seem to have broken out of that old seasonal cycle. We now hold better cow condition at critical times and our pastures seem to be performing better. However, clover content and performance is still a major problem.

\section{Conclusion}

Split-calving has proven to be a very productive and profitable system. We have changed the pattern of feed 
demand over the year to better suit our pasture growth patterns.

Production is achieved with minimal extra inputs compared with seasonal calving, and with a lot less stress on the cows and the pastures.

In a large herd like ours, the work-load is more evenly spread allowing more interesting work for the staff throughout the year. It is now easier to roster holidays and time off through the year. This suits all of us!
Analysis of our economic farm surplus shows that we are significantly more productive and profitable than the average Northland dairy farm. Our average payout (including the winter incentive) is equal to the best payouts in the country, and our profitability is comparable to the supposedly more favoured dairy areas.

The challenge in Northland is to find a management system that best suits the pasture growth patterns and soil conditions on your farm. I believe that we have found ours. 